Jurnal Gizi dan Dietetik Indonesia

Vol. 5, No. 1, 2017: 17-22
Tersedia online pada: http://ejournal.almaata.ac.id/index.php/IJND DOI : http://dx.doi.org/10.21927/ijnd.2017.5(1).17-22

\title{
Tepung okra (Albelmoschus esculantus) menurunkan rasio kadar LDL terhadap HDL tikus hiperkolesterolemia
}

\author{
Ayu Febriyatna ${ }^{1}$, Agatha Widiyawati ${ }^{1}$
}

${ }^{1}$ Program Studi Gizi Klinik, Politeknik Negeri Jember, Jl. Mastrip Kotak Pos 164 Jember

\begin{abstract}
ABSTRAK
Latar belakang: Hiperkolesterolemia adalah salah satu penyebab penyakit jantung yang ditandai dengan kadar kolesterol Low Density Lipoprotein (LDL) yang tinggi dan kadar kolesterol High Density Lipoprotein (HDL) yang rendah. Okra (Albelmoschus esculantus) dalam bentuk tepung mengandung serat yang tinggi dan kandungan bioaktif seperti flavonoid.

Tujuan: penelitian ini untuk mengetahui efektifitas tepung okra terhadap perubahan kadar kolesterol HDL dan LDL pada tikus putih model hiperkolesterolemia.

Metode: Desain penelitian ini yaitu true experimental dengan Kelompok Kontrol (Pretest-Posttest with Control Goup). Tikus putih jantan (Rattus novergicus) yang berumur 8-10 minggu dengan bobot antara 150-200 g dibagi kedalam 4 kelompok. Tikus dibuat hiperkolesterolemia menggunakan pakan HFD dengan dosis $4 \mathrm{mg} / 100 \mathrm{~g}$ BB tikus perhari selama 14 hari. Selanjutnya, tikus hiperkolesterolemia diberi pakan pakan standart dan tepung okra dengan dosis yang berbeda yaitu kelompok KP (Kontrol Positif) hanya diberi pakan standar, kelompok P1 (tepung okra dosis 0,09 g/200 g BB tikus perhari), kelompok $P 2$ (tepung okra dosis 0,18 g/200 g BB tikus perhari), dan kelompok P3 (tepung okra dosis 0,36 g/200 g $B B$ tikus perhari) selama 10 hari. Data dianalisis menggunakan One Way ANOVA dan paired t-test.

Hasil: Tikus percobaan pada semua kelompok tidak terjadi perubahan berat badan yang signifikan. Kadar kolesterol HDL mengalami peningkatan yang signifikan pada kelompok $P 3$ dengan dosis tepung okra 0,36 g/200 g dibandingkan dengan kelompok yang lainnya. Kelompok P3 juga mampu menurunkan kadar kolesterol LDL.

Kesimpulan: tepung okra (albelmoschus esculantus) pada dosis 0,36 g/200 g BB tikus/hari selama 10 hari secara bermakna berpengaruh terhadap peningkatan kadar kolesterol HDL dan penurunan kadar kolesterol LDL tikus model hiperkolesterolemia
\end{abstract}

KATA KUNCI: Hiperkolestrolemia, High Density Lipoprotein (HDL), Low Density Lipoprotein (LDL), tepung okra.

\section{Okra flour (Albelmoschus esculantus) attenuated the ratio of LDL to HDL level in hypercholesterolemic rats}

\begin{abstract}
Backgounds: Hypercholesterolemia is one cause of heart disease with high levels of Low Density Lipoprotein ( $L D L)$ cholesterol and low levels of high density lipoprotein (HDL) cholesterol. Okra (Albelmoschus esculantus) flour contain high fibers and more bioactive compound such as flavonoids. Objectives: This study aimed to examine the effectiveness of okra flour against the Low Density Lipoprotein $(L D L)$ cholesterol level and high density lipoprotein (HDL) cholesterol level in Hypercholesterolemic rats.

Methods: Design of the research experimental design with pre-and posttest control goup.Male white (rattus norvegicus) aged 8-10 weeks with body weight of 150-200 g were used, then divided into 4 goups of 8 rats. Rats made Hypercholesterolemia used Haight Fat Diet (HFD) feed at a doses $4 \mathrm{mg} / 100 \mathrm{~g}$ body weight for 14 days. After that, Hypercholesterolemic rats were provided by standard diet rats given standart feed and okra flour with different doses it was goups positive control (KP) not given flour okra, okra flour doses $0.09 \mathrm{~g} / 200 \mathrm{~g}$ body weight (P1), okra flour doses $0.18 \mathrm{~g} / 200 \mathrm{~g}$ body weight (P2), and okra flour doses $0.36 \mathrm{~g} / 200 \mathrm{~g}$ body weight (P3). The data was analyzed using One Way ANOVA dan paired t-test.
\end{abstract}


Results: Rats in all goup did not experience changes in body weight significantly. Concentration of HDL cholesterol increased significantly in P3 goups with doses okra flour $0.36 \mathrm{~g} / 200 \mathrm{~g}$ body weight compared withe the other goups. P3 goups attenuated the concentration of LDL cholesterol.

Conclusions: the administration okra flour (albelmoschus esculantus) at doses $0.36 \mathrm{~g} / 200 \mathrm{~g}$ body weight improved HDL cholesterol and decreased LDL cholesterol concentration in Hypercholesterolemic rats model.

KEYWORDS: Hypercholesterolemic High Density Lipoprotein (HDL), Low Density Lipoprotein (LDL) and Okra Flour.

\section{PENDAHULUAN}

Indonesia merupakan Negara berkembang dan telah mengalami perbaikan di segala bidang Dampak negatif dari pergeseran tersebut adalah perubahan pola makan dan timbulnya berbagai penyakit degeneratif salah satunya adalah penyakit jantung koroner (PJK). Penyakit Kardiovaskuler, terutama PJK yang ditandai dengan serangan jantung masih menempati peringkat pertama penyebab kematian di Indonesia (1).

Hiperkolesterolemia adalah salah satu penyebab penyakit jantung. Prevalensi penderita hiperkolesterolemia di Indonesia pada tahun 2013 dilihat dari kadar kolesterol total abnormal sebesar 35,9\% dan diperkirakan penderita hiperkolesterolemia akan semakin meningkat (2). Penyakit hiperkolesterolemia merupakan kelainan metabolisme lipid yang ditandai dengan peningkatan kolesterol Low Density Lipopretein (LDL) dan penurunan kadar kolesterol High Density Lipoprotein (HDL) (3).

Pemanfaatan tumbuhan sebagai obat sudah dilakukan sejak dulu oleh masyarakat Indonesia. Buah dan sayur merupakan asupan zat gizi yang tinggi kandungan serat dan mengandung antioksidan berupa flavonoid (quercetin, kaempferol, myricetin, apigenin, luteolin, vitexin dan isovitexin) yang memiliki sifat antioksidan. Flavonoid merupakan zat aktif yang memiliki pengaruh terhadap profil lipid dengan cara mengaktifkan sistem multi enzim seperti cytochrome $p$-450 dan b5 yang mempunyai fungsi mengikat kadar kolesterol dan cairan empedu yang dieksresikan $(4,5)$.

Salah satu sayuran yang tinggi akan serat dan kandungan flavonoidnya adalah okra (Albelmoschus esculantus). Tanaman okra (Albelmoschus esculantus) Dalam $100 \mathrm{~g}$ buah okra mengandung kadar air 90,17 g, Energi 31 kkal, protein 2 g, lemak total $0,10 \mathrm{~g}$, abu $0,70 \mathrm{~g}$, karbohidrat $7,03 \mathrm{~g}$, total serat 3,2 g, Ca $81 \mathrm{mg}, \mathrm{Fe} \mathrm{0,8} \mathrm{mg,} \mathrm{vitamin} \mathrm{A} 375 \mathrm{IU}$, Vitamin C 21,1 mg, Vitamin E 0,36 g, vitamin K 53 $\mathrm{mg}$, Tiamin 0,02 $\mathrm{mg}$, dan riboflavin 0,06 mg (6).

Penelitian okra segar telah banyak dilakukan untuk mengatasi hiperkolesterolemia sedangkan penelitian okra dalam tekstur tepung belum pernah dilakukan. Okra dalam tekstur tepung memiliki daya simpan yang lama, nilai ekonomi yang tinggi, kandungan zat gizi dan senyawa bioaktif yang lebih banyak. Perlu dikaji efikasi sejauh mana potensi tepung okra dalam menurunkan kadar kolesterol total.

Berdasarkan uraian diatas maka peneliti menganalisis pengaruh pemberian tepung okra baik sebagai pangan fungsional maupun pengembangan formula enteral terhadap efektifitas dalam menurunkan kadar kolesterol LDL dan meningkatkan kadarkolesterol HDL pada tikus putih model hiperkolesterolemia.

\section{BAHAN DAN METODE}

Penelitian ini merupakan penelitian true experimental dengan kelompok kontrol (PretestPosttest with Control Goup). Penelitian dilakukan di Laboratorium Biomedik Universitas Negeri Jember (UNEJ) pada bulan Agustus-Oktober 2017. Sampel penelitian adalah tikus putih (Rattus novergicus) jantan berumur 8-10 minggu dengan bobot berat badan antara 150-200 g dalam kondisi sehat. Variabel bebas dalam penelitian ini ialah pemberian tepung okra sedangkan variabel tergantung adalah kadar kolesterol HDL dan LDL.

Besar sampel mengacu pada standar yang dianjurkan WHO yaitu minimal 5 ekor tikus. 
Penelitian ini menggunakan 8 ekor tikus untuk setiap kelompok. Penambahan 3 ekor tikus pada setiap kelompok bertujuan untuk mengantisipasi drop out. Jumlah tikus yang digunakan dalam penelitian sebanyak 32 ekor yang dibagi secara random menjadi 4 kelompok penelitian yaitu kelompok KP (kontrol positif) hanya diberikan pakan High Fat Diet (HFD), kelompok P1 diberikan pakan HFD dan tepung okra dosis $0,09 \mathrm{~g} / 200 \mathrm{~g}$ BB tikus perhari, Kelompok P2 diberikan pakan HFD dan tepung okra dosis $0,18 \mathrm{~g} / 200 \mathrm{~g}$ BB tikus perhari dan kelompok $\mathrm{P} 3$ diberikan diet HFD dan tepung okra dosis $0,36 \mathrm{~g} / 200 \mathrm{~g}$ BB tikus perhari.

Aklimatisasi dilakukan diawal penelitian selama 7 hari dengan tujuan untuk menyesuaikan kondisi hewan coba pada keadaan stres yang sama dan penyesuaian terhadap lingkungan. Selanjutnya diberikan pakan High Fat Diet (HFD) yaitu butter sebanyak $4 \mathrm{ml} / 100 \mathrm{~g}$ BB tikus/hari, selama 14 hari melalui sonde lambung kemudian dilakukan pemeriksaan kadar kolesterol total setelah pemberian pakan HFD (7). Penelitian dilanjutkan dengan pemberian tepung okra, secara empiris konsumsi okra pada manusia yang dapat dikonsumsi $20 \mathrm{~g}$ pada setiap harinya, kemudian dikonvesikan ke tikus. Pemberian tepung okra diberikan melalui sonde lambung selama 10 hari Dosis tepung okra sebanyak 0,09 g/200 g BB tikus perhari pada kelompok $\mathrm{P} 1$, sebanyak $0,18 \mathrm{~g} / 200 \mathrm{~g} \mathrm{BB}$ tikus perhari pada kelompok $\mathrm{P} 2$ dan sebanyak 0,36 g/200 g BB tikus perhari pada kelompok P3. Data pretest kadar kolesterol darah tikus diperiksa setelah 10 hari pemberian pakan HFD sedangkan data post-test diambil setelah 14 hari pemberian tepung okra.

Tepung okra diberikan dalam bentuk suspensi agar memudahkan dalam pemberiannya ke tikus. Suspensi diberikan secara oral menggunakan sonde yang diberikan kepada tikus untuk melihat efeknya terhadap penurunan kadar kolesterol LDL dan meningkatkan kadar kolesterol HDL. Pemberian tepung okra dilarutkan dengan volume pengenceran 1:5 dengan frekuensi pemberian disesuaikan dengan volume lambung tikus yaitu $5 \mathrm{~mL}$.

Kadar HDL diukur menggunakan spektrofotometer Microlab 300 dengan metode uji fotometrik enzimatik cholesterol oxidasepaminophenazone (CHOD-PAP). Kadar LDL diukur menggunakan spektrofotometer Microlab 300 dengan metode uji fotometrik CHOD-PAP.

Data dianalisis menggunakan uji One Way Anova untuk mengetahui perbedaan pengaruh dari 4 kelompok perlakuan dan uji paired t-test untuk mengetahui uji beda 2 kelompok berpasangan sebelum dan sesudah perlakuan pada masingmasing kelompok.

\section{HASIL}

\section{Karakteristik Hewan Coba}

Berdasarkan hasil uji statistik rerata berat badan tikus pada masa aklimatisasi menunjukkan hasil tidak signifikan yaitu $p>0,05(P=0,089)$ sehingga dapat disimpulkan bahwa sampel tikus sudah homogen pada semua kelompok (Tabel 1).

\section{Perubahan Kondisi Tikus Selama Penelitian}

Penelitian dimulai dengan mengadaptasikan 32 ekor tikus selama 7 hari untuk menyesuaikan kondisi hewan coba pada keadaan stres yang sama dan penyesuaian terhadap lingkungan. Selanjutnya, tikus percobaan diberikan pakan HFD selama 14 hari. Perlakuan tersebut mengakibatkan kematian tikus sebanyak 5 ekor. Sedangkan pemberian tepung okra selama 10 hari mengakibatkan kematian tikus sebanyak 2 ekor. Sehingga pada kelompok KP tersisa 6 ekor, P1 sebanyak 7 ekor, $\mathrm{P} 2$ sebanyak 5 ekor dan $\mathrm{P} 3$ sebanyak 7 ekor.

Perubahan BB tikus setelah diberi pakan HFD selama 14 hari tidak berbeda secara signifikan setelah dan sebelum diberikan pakan HFD $(P>0,05)$ (Tabel 1).

Hasil penelitian juga menunjukkan bahwa setelah diberi pakan standar dan tepung okra selama 10 hari tidak terjadi perubahan secara signifikan $(P>0,05)$ (Tabel 1).

Sehingga dapat disimpulkan bahwa pemberian perlakuan tidak berpengaruh pada perubahan BB tikus.

\section{Kadar HDL}

Pemeriksaan kadar HDL dari serum darah tikus dilakukan sebanyak 2 kali, yaitu sebelum 
dan sesudah perlakuan. Hasil uji one-way ANOVA menunjukkan bahwa data kadar HDL pre test dan post test seluruh kelompok tidak ada perbedaan yang signifikan antar kelompok $(P>0,05)$. Data disajikan pada Tabel 2.

Hasil kadar HDL pre test dan post test tiap kelompok dengan uji paired $t$-test menunjukkan bahwa kelompok P3 dengan dosis $0,36 \mathrm{~g} / 200 \mathrm{~g} \mathrm{BB}$ tikus perhari berbeda secara signifikan dibandingkan dengan kelompok P1 dan P2 $(P<0,05)$. Selisih (Delta) kadar HDL Tikus pada kelompok P3 memiliki selisih nilai yang lebih besar yakni $28,70 \pm 22,27$ dibandingkan dengan kelompok lainnya (Tabel 3). Hal ini menunjukkan bahwa dosis tepung okra $36 \mathrm{~g} / 200 \mathrm{~g}$ BB tikus perhari mampu meningkatkan kadar HDL.

\section{Kadar LDL}

Berdasarkan Tabel 4, pemeriksaan kadar LDL dari serum darah tikus seluruh kelompok penelitian sebelum maupun sesudah perlakuan menunjukkan tidak ada perbedaan yang signifikan $(P>0,05)$.

Berdasarkan Tabel 5, dapat diketahui bahwa kelompok P3 memiliki selisih nilai penurunan kadar
LDL yang signifikan dibandingkan dengan kelompok lainnya $(P>0,05)$. selisih penurunan yang terjadi pada kelompok $\mathrm{P} 3$ sebesar $25,83 \pm 23,15 \mathrm{mg} / \mathrm{dl}$. Kondisi ini menunjukkan bahwa pemberian tepung okra dengan dosis $36 \mathrm{~g} / 200 \mathrm{~g}$ BB tikus perhari mampu menurunkan kadar LDL.

\section{Hasil Analisa Kandungan Zat Gizi Tepung Okra}

Kandungan zat gizi tepung okra pada penelitian ini diketahui mengandung serat pangan $14,21 \%$ dan flavonoid $202 \mathrm{ppm}$ dalam $100 \mathrm{~g}$ tepung okra. Selain itu, tepung okra pada penelitian ini juga diketahui memiliki kadar air sebesar $6,36 \%$, lemak sebesar $2 \%$ dan protein sebesar $13,84 \%$ (Data Primer, 2107).

\section{BAHASAN}

Penyakit hiperkolesterolemia merupakan kelainan metabolisme lipid yang ditandai dengan peningkatan kolesterol Low Density Lipopretein (LDL) dan penurunan kadar kolesterol High Density Lipoprotein (HDL) (3). Induksi hiperkolesterolemia

Tabel 1. Rerata berat badan tikus selama penelitian

\begin{tabular}{|c|c|c|c|c|c|}
\hline \multirow[b]{2}{*}{ Berat Badan } & \multicolumn{4}{|c|}{ Kelompok Penelitian } & \multirow[b]{2}{*}{$p$-value } \\
\hline & $\begin{array}{c}\mathrm{KP} \\
\text { mean } \pm S D\end{array}$ & $\begin{array}{c}\mathrm{P} 1 \\
\text { mean } \pm S D\end{array}$ & $\begin{array}{c}\text { P2 } \\
\text { mean } \pm S D\end{array}$ & $\begin{array}{c}\mathrm{P3} \\
\text { mean } \pm S D\end{array}$ & \\
\hline Sebelum diet HFD & $167,92 \pm 12,00$ & $175,86 \pm 15,21$ & $188,6 \pm 10,78$ & $173,21 \pm 11,93$ & 0,089 \\
\hline Sesudah diet HFD/Sebelum tepung Okra & $176,83 \pm 8,94$ & $184,57 \pm 15,41$ & $193,80 \pm 14,57$ & $177,00 \pm 13,69$ & 0,150 \\
\hline Sesudah Tepung Okra & $175,68 \pm 10,97$ & $174,83 \pm 27,48$ & $187,62 \pm 17,84$ & $174,43 \pm 14,16$ & 0,632 \\
\hline
\end{tabular}

Sumber : Data Primer, 2017

Tabel 2. Hasil Uji One-way ANOVA perbedaan rerata kadar HDL

\begin{tabular}{lc}
\hline \multicolumn{1}{c}{ Perlakuan } & $\boldsymbol{P}$ value \\
\hline Pre Test (seluruh kelompok) & 0,079 \\
Post Test (seluruh kelompok) & 0,174 \\
\hline
\end{tabular}

Sumber : Data Primer, 2017

Tabel 3. Perbedaan rerata kadar HDL sebelum dan sesudah perlakuan

\begin{tabular}{ccccc}
\hline Kelompok & $\begin{array}{c}\text { Pre-test } \\
\text { Mean } \pm \text { SD }\end{array}$ & $\begin{array}{c}\text { Post-test } \\
\text { Mean } \pm \text { SD }\end{array}$ & Delta $\boldsymbol{~}$ & P Value \\
\hline KP & $50,82 \pm 11,55$ & $62,11 \pm 31,05$ & $11,36 \pm 24,30$ & 0,308 \\
P1 & $47,00 \pm 9,92$ & $52,08 \pm 27,05$ & $5,02 \pm 20,59$ & 0,536 \\
P2 & $46,82 \pm 16,59$ & $65,95 \pm 31,95$ & $21,00 \pm 23,09$ & 0,401 \\
P3 & $38,48 \pm 10,00$ & $67,24 \pm 17,96$ & $28,70 \pm 22,27$ & $0,014^{*}$ \\
\hline
\end{tabular}

*) Ada perbedaan bermakna

Sumber : Data Primer, 2017 
Tabel 4. Hasil uji One-way ANOVA perbedaan rerata kadar LDL

\begin{tabular}{lc}
\hline \multicolumn{1}{c}{ Perlakuan } & p-value \\
\hline Pre Test (seluruh kelompok) & 0,755 \\
Post Test (seluruh kelompok) & 0,696 \\
\hline
\end{tabular}

Sumber: Data Primer, 2017

Tabel 5. Perbedaan rerata kadar LDL sebelum dan sesudah perlakuan

\begin{tabular}{ccccc}
\hline Kelompok & $\begin{array}{c}\text { Pre-test } \\
\text { Mean } \pm \text { SD }\end{array}$ & $\begin{array}{c}\text { Post-test } \\
\text { Mean } \pm \text { SD }\end{array}$ & Delta $\boldsymbol{\Delta}$ & $\boldsymbol{p}$-value \\
\hline KP & $53,80 \pm 26,81$ & $42,49 \pm 9,70$ & $11,31 \pm 25,79$ & 0,332 \\
P1 & $65,79 \pm 26,51$ & $39,03 \pm 19,90$ & $17,17 \pm 9,91$ & 0,100 \\
P2 & $59,91 \pm 22,04$ & $42,59 \pm 7,24$ & $14,6 \pm 20,16$ & 0,181 \\
P3 & $67,26 \pm 27,60$ & $42,88 \pm 14,40$ & $25,83 \pm 23,15$ & $0,041^{*}$ \\
\hline
\end{tabular}

*) Ada perbedaan bermakna

Sumber: Data Primer, 2017

dapat dilakukan dengan pemberian pakan High Fat Diet (HFD). Selama pemberian pakan HFD selama 14 hari, BB tikus cenderung mengalami peningkatan $\mathrm{BB}$ sebelum dan sesudah diberi pakan HFD. Induksi diet tinggi lemak pada tikus mampu memodulasi mikrobiota usus sehingga terjadi peningkatan permeabilitas dan kemampuan absorpsi usus $(8,9)$.

Hasil penelitian ini juga menunjukkan bahwa semua kelompok yang diberi tepung okra setelah pakan HFD cenderung mengalami penurunan BB. Hal ini dikarenakan sifat fisik tepung okra yang dapat membentuk gel dan meningkatkan viskositas saluran cerna sehingga menurunkan absorpsi makanan oleh usus. Penelitian lain di Spanyol pada tahun 2010, menyatakan bahwa konsumsi serat meningkatkan viskositas melalui pembentukan lapisan gel dan bersifat impermeable di saluran gastrointestinal (10). Pembentukan gel oleh serat mampu menghalangi kontak makanan dengan dinding saluran cerna (11).

Tepung okra sebagai sediaan yang digunakan pada penelitian ini terbukti mampu meningkatkan kadar kolesterol HDL dan menurunkan kadar kolesterol LDL. Dosis tepung okra 0,36 g/200 g BB tikus perhari dapat meningkatkan kadar kolesterol $\mathrm{HDL}$, sebesar 28,70 $\pm 22,27 \mathrm{~g}$ dan menurunkan kadar kolesterol LDL sebesar 25,83 $\pm 23,15 \mathrm{~g}$. Kandungan tepung okra yang terdiri atas serat pangan dan senyawa bioaktif seperti flavonoid diduga mampu meningkatkan kadar kolesterol HDL dan menurunkan kadar kolesterol LDL tikus.
Okra segar memiliki flavonoid yakni kuersetin dalam jumlah $60-75 \%$. Senyawa kuersetin berperan dalam mencegah proses oksidasi dari LDL dengan cara menangkap radikal bebas selain itu kuersitin juga memiliki aktifitas dalam menurunkan kadar kolesterol (12-14)senyawasenyawa flavonoid alami seperti quercetin memiliki aktivitas perlindungan yang bervariasi terhadap penurunan kandungan $\alpha$-tokoferol dalam LDL sedangkan kaempferol dan morin kurang efektif dibandingkan dengan myricetin dan quercetin. Komponen $\alpha$-tokoferol (bentuk umum vitamin $\mathrm{E}$ ) dikenal sebagai antioksidan primer yang dapat melindungi LDL dari oksidasi (15).

Serat pangan dapat mengikat kolesterol LDL secara langsung, mengikat asam empedu dan menghambat sirkulasi enterohepatik asam empedu. Mekanisme ini akan memacu kehilangan kolesterol LDL dengan cara meningkatkan pengeluaran kolesterol LDL melalui feses. Selain itu penambahan beberapa jenis serat pada manusia dapat menurunkan kadar LDL $(16,17)$. Oleh karena itu, kandungan flavonoid dan serat pada tepung okra diduga dapat meningkatkan kadar kolesterol HDL dan menurunkan kadar kolesterol LDL.

\section{KESIMPULAN DAN SARAN}

Pemberian tepung okra (albelmoschus esculantus) pada dosis dosis $0,36 \mathrm{~g} / 200 \mathrm{~g}$ BB tikus/ hari selama 10 hari secara bermakna berpengaruh terhadap peningkatan kadar kolesterol HDL dan 
penurunan kadar kolesterol LDL tikus model hiperkolesterolemia.

Berdasarkan kesimpulan diatas, perlu dilakukan penelitian lebih lanjut tentang pemberian modifikasi formula enteral tepung okra tehadap peningkatan HDL dan penurunan LDL, serta pemanfaatan tepung okra sebagai alternatif makanan tambahan untuk penderita hiperkolesteolemia.

\section{UCAPAN TERIMAKASIH}

Peneliti berterimakasih kepada Penerimaan Negara Bukan Pajak (PNBP) yang telah memberikan bantunan dana penelitian dengan nomor kontrak 699/PL17.4/PL/2017.

\section{DAFTAR PUSTAKA}

1. Inayati, Rosidah, in Hardinsyah. Penatalaksanaan diet penyakit jantung. In: I Dewa Nyoman Supariasa, editor. ILMU GIZI Teori \& Aplikasi. Jakarta: EGC; 2014.

2. Kemenkes RI. Riset Kesehatan Dasar RISKESDAS 2013. 2013;

3. Botham, Kathlee M, Mayes Peter A. Sintesis, transpor \& ekskresi kolesterol. In: Biokimia Harper. 27th ed. Jakarta: EGC Buku Kedokteran; 2009.

4. Rodwell; RKMPAMDKG victor W. Biokimia Harper edisi 25. 2003;

5. Redha A. Flavonoid: struktur, sifat antioksidatif dan peranannya dalam sistem biologis Abdi Redha. J Belian. 2010;9(2):196-202.

6. Roy A, Shrivastava SL, Mandal SM. Functional properties of Okra Abelmoschus esculentus L. (Moench): traditional claims and scientific evidences. Plant Sci Today. 2014;1(3):12130.

7. Oktasari R. Pengaruh pemberian jus labu siam (Sechium edule (Jacq.) Swartz) terhadap profil lipid tikus (Rattus novergicus) model hiperlipidemia. Universitas Sebelas Maret; 2015.

8. Nissa C, Madjid IJ. Potensi glukomanan pada tepung porang sebagai agen anti-obesitas pada tikus dengan induksi diet tinggi lemak. $\mathrm{J}$ Gizi Klin Indones (The Indones J Clin Nutr. 2016;13(1):1-6.

9. Cani PD, Knauf C, Iglesias MA, Drucker DJ, Delzenne NM, Burcelin R, et al. Improvement of glucose tolerance and hepatic insulin sensitivity by oligofructose requires a functional glucagonlike peptide 1 receptor. Diabetes [Internet]. 2006 May 1 [cited 2017 Dec 12];55(5):1484-90. Available from: http://www.ncbi.nlm.nih.gov/ pubmed/16644709

10. Johnson IT, Gee JM. Effect of gel-forming gums on the intestinal unstirred layer and sugar transport in vitro. Gut. 1981 May;22(5):398403.

11. Elsenhans B, Zenker D, Caspary WF. Guaran Effect on Rat Intestinal Absorption: A Perfusion Study. Gastroenterology. 1984;86(6):645-53.

12. Widyaningsih W. Uji aktivitas antioksidan ekstrak etanol daun dewa (Gynura procumbens) dengan metode DPPH (1,1-difenil-2-pikrilhidrazil). In: Prosiding Seminar Nasional Kosmetika Alami . Yogyakarta; 2010. p. 109-15.

13. Seiva FR, Gustavo Chuffa LA, Pereira Braga C, Paulo Amorim JA, Angélica Fernandes $\mathrm{AH}$. Quercetin ameliorates glucose and lipid metabolism and improves antioxidant status in postnatally monosodium glutamate-induced metabolic alterations. FOOD Chem Toxicol. 2012;50:3556-61.

14. Waji RA, Sugrani A. Makalah kimia organik bahan alam flavonoid (quertecin). 2009;23.

15. Zhu QY, Huang Y, Chen Z-Y. Interaction between flavonoids and $\alpha$-tocopherol in human low density lipoprotein. J Nutr Biochem. 2000 Jan 1;11(1):14-21.

16. Hartoyo A, Erma Rohmawati dan. Pengaruh fraksi nonprotein kacang komak (Lanlab purpureus (L.) Sweet) terhadap kadar glukosa darah dan malonaldehida tikus diabetes. Has Penelit JTeknol dan Ind Pangan. 2010;XXI(1).

17. Wresdiyati T, Hartanta AB, Astawan M. Tepung Rumput Laut (Eucheuma Cottonii ) Menaikkan Level Superoksida Dismutase ( Sod ). J Vet. 2011;12(2):126-35. 